\title{
Knowledge and Circulation of Plants: Unveiling the Participation of Amazonian Indigenous Peoples in the Construction of Eighteenth and Nineteenth Century Botany
}

\author{
Nelson Sanjad \\ Museu Paraense Emílio Goeldi, \\ Brazil \\ nsanjad@museu-goeldi.br
}

\author{
Ermelinda Pataca \\ Universidade de São Paulo, \\ Brazil \\ ermelinda.pataca@gmail.com
}

\author{
Rafael Rogério \\ Nascimento dos Santos \\ Universidade Federal do Sul e \\ Sudeste do Pará, Brazil \\ rafaelsantos@unifesspa.edu.br
}

Abstract: This article gives visibility to Amazonian indigenous peoples in the global process of plant circulation and associated knowledge. The first part highlights the indigenous role in cultivating and collecting native plants, and in the processing of natural products over the second half of the eighteenth century. The second part shows that these activities were influenced by internal colonial dynamics, as well as by international relations. The case of the ayapana herb is analysed in detail. This plant became known worldwide at the beginning of the nineteenth century thanks to the interactions among indigenous knowledge, Portuguese colonial politics and the performance of military and naturalists of different nationalities. Examples like this show that, in the process of building botany, which occurred concurrently with the globalization of plants, indigenous peoples provided not only specimens that circulated around the world, but also knowledge related to cultivation, transportation and uses.

Keywords: indigenous peoples; circulation of knowledge; traveling naturalists; botany; Amazon 


\section{Introduction}

In the second half of the eighteenth century, Portugal experienced a quite intense reformist context that started with rebuilding Lisbon after the 1755 earthquake. Planned by Sebastiano José de Carvalho e Melo, minister of D. José I, the reforms combined urbanization projects and technical and scientific rationality, aiming at boosting trade, mining, agricultural and industrial activities, in order to overcome the delay in which the elites believed the country was immersed. To achieve these goals, policies were prepared, and some institutions were founded or renewed with the purpose of developing experimental sciences in Portugal and its colonies. ${ }^{1}$

The reformist projects' implementation not only mobilized a comprehensive professional staff but also the general population, an aspect that is rarely mentioned in historiography. At first, foreign teachers were hired by Coimbra University after the 1772 reforms, simultaneously with the construction of new institutions to conduct experimental activities and nature observation. Within this context, we highlight the role of the physician and naturalist Domenico Vandelli, who was hired to occupy the chemistry and natural history chairs in Coimbra. He was responsible for idealizing and executing a series of projects with the aim of developing natural history in Portugal, such as the construction of a natural history museum, a chemistry laboratory, and a botanical garden at the University of Coimbra. These institutions were absolutely important for training naturalists, physicians and mathematicians, as well as for coordinating and conducting investigations about animals, plants and minerals in order to encourage trade and industry.

Vandelli also prepared an extensive project with the purpose of investigating topics that were related to natural philosophy and the political, economic and social situation of the Portuguese empire, named "História Natural das Colónias" (Natural History of the Colonies). That project covered an integrated complex with the construction of the Museum and Botanical Garden of Ajuda, in the Royal Palace near Lisbon, concluded in 1768, and "philosophical travels." The aims of these travels were geographic exploration and scientific and social investigation that covered the Kingdom's territory, as well as that of the American, African, and Asian colonies between 1783 and 1808. The Botanical Garden of Ajuda supervised at a distance and was established as the locus of study of botany and experiments with plants for application in agriculture, medicine, and industry. ${ }^{2}$

\footnotetext{
${ }^{1}$ José A. França, Une ville des lumières: La Lisbonne de Pombal (Paris: SEVPEN, 1965); Oswaldo Munteal Filho, "Uma Sinfonia para o Novo Mundo: a Academia Real de Ciências de Lisboa e os caminhos da Ilustração luso-brasileira na crise do Antigo Sistema Colonial." (PhD diss., Universidade Federal do Rio de Janeiro, 1998).

${ }^{2}$ William J. Simon, Scientific Expeditions in the Portuguese Overseas Territories (1783-1808) and the role of Lisbon in the Intellectual-Scientific Community of the late Eighteenth Century (Lisboa: IICT, 1983); Ângela Domingues, Viagens de exploração geográfica na Amazónia em finais do século XVIII: Política, Ciência e Aventura (Lisboa: Secretaria Regional do Turismo, Cultura e Emigração/Centro de Estudos de História do Atlântico, 1991); João Brigola, Colecçôes, gabinetes e museus em Portugal no séc. XVIII (Lisboa: FCG/
} 
According to eighteenth century physiocratic thinking, all travellers who left Lisbon to the colonies combined investigation on natural history to politics implementation, which, above all, tried to diversify the economy through agricultural developments. These politics included the prospection of new cultivars, domestication of native plants and acclimatization of exotic species, increase in agricultural productivity by adopting modern techniques and equipment, incentive to industries related to farming production, such as weaving and dyeing, training of technical staff, distribution of specialized publications, etc. ${ }^{3}$ With this scope in mind, the Crown-commissioned travellers who had as their primary functions the collection, preparation, description and shipment of specimens and products from the animal, plant and mineral kingdoms to the metropolis' museums and gardens.

These products were subjected to experiments as well as to chemical and mechanical tests, for instance, to identify wood properties, pigments, balms, resins, and fibres used as raw material in the emergent industry. This is the reason why botany and agriculture were the travellers' priorities, which resulted in the predominance, among the vast collections gathered, of representations and samples related to the plant world, such as memories, journals, instructions, drawings, herbaria, and also live plants. ${ }^{4}$

The study of plants also encompassed the inventory and the documentation of local populations' experience, especially indigenous peoples, on the use of plants in food, medicine, and industry. This recommendation was recorded in the instructions for philosophical travels to be made in the Portuguese empire, written by Vandelli. He, as an example, highlighted the indigenous knowledge about the medicinal properties of plants and the extraction of dyes used in the textile industry: "The indigenous peoples, since they are the smartest practitioners in that continent [Americas], are also the best masters to teach us the names of plants and their uses, particularly those from which colours can be extracted and those used for the diseases that were typical to that part of the Americas where they live." 5 This procedure resulted in thorough reports about the ways in which colonial society used native plants.

FCT, 2003); Nívea Santos, "O palácio de Queluz e o mundo ultramarino: circuitos ilustrados (Portugal, Brasil e Angola, 1796-1803)." (PhD diss., Universidade Federal Fluminense, 2013); Ermelinda Pataca, "Mobilidades e permanências de viajantes no Mundo Português: entre práticas e representaçóes científicas e artísticas." (Tese de Livre-Docência, Universidade de São Paulo, 2015).

${ }^{3}$ Maria Odila da Silva Dias, "Aspectos da ilustração no Brasil," Revista do Instituto Histórico e Geográfico Brasileiro 278 (1968): 105-70; Fernando Novais, Portugal e Brasil na crise do antigo sistema colonial (São Paulo: Hucitec, 1979).

${ }^{4}$ Miguel Figueira de Faria, A imagem útil. José Joaquim Freire (1760-1847), desenhista topográfico e de história natural: arte, ciência e razão de Estado no final do Antigo Regime (Lisboa: UAL, 2001); Ermelinda Pataca, "Terra, água e ar nas viagens científicas portuguesas (1755-1808)." (PhD diss., Universidade Estadual de Campinas, 2006); Ermelinda Pataca, "Coletar, preparar, remeter, transportar-práticas de História Natural nas viagens filosóficas portuguesas (1777-1808)," Revista Brasileira de História da Ciência 4 (2011): 125-38.

${ }^{5}$ Domenico Vandelli, Viagens Filosóficas ou Dissertação sobre as importantes regras que o Filosofo naturalista, 
In the State of Gráo-Pará and Rio Negro, an administrative unit of the Portuguese empire in the Americas, corresponding in part to the current Brazilian Amazon, indigenous peoples made most of the workforce and military personnel. They took part in travels across the territory as guides, translators, pilots, oarsmen, cooks, porters, as well as collectors, taxidermists, herbalists, and technical assistants for preparing memories, drawings, and maps. Thus, they were in charge of several travel-related tasks and are currently seen as essential agents in colonial investigations. ${ }^{6}$ Without acknowledging their involvement, it would be hard to think about developing botany and agronomy. Both sciences became instruments of the metropolitan administration, to provide, through specialized knowledge, the growth of the colonial economy.

Accordingly, this article intends to highlight two essential points that need to be investigated: first, the full acknowledgement of the indigenous involvement in the colonial enterprise every time it requested the identification, collection, cultivation, transportation, and processing of natural products. This is not a new issue, on the contrary; but further research is needed to question the sources about the knowledge involved in these activities and about the agency of indigenous peoples when they integrated the colonial enterprises, including by joining their own knowledge with others that they were learning and adjusting. Such investigations are important to better understand and characterize the participation of indigenous peoples in a coordinated network of identification, collection, and transportation of plants, which was essential for developing botany and agronomy.

The second point, which is connected to the first one, refers to the process of global circulation of plants and associated knowledge. The history of some Amazon-native plant species, originally used by indigenous peoples, has been the subject of extensive investigations, since they were incorporated into different colonial societies and globalized throughout the eighteenth and nineteenth centuries, with great impact on the international economy. This is the case of cinchona (Cinchona officinalis L.) and that of the rubber tree (Hevea brasiliensis

nas suas peregrinaçôes deve principalmente observar (1779), 35.

${ }^{6}$ Ângela Domingues, Quando os indios eram vassalos: colonização e relaçóes de poder no norte do Brasil na segunda metade do século XVIII (Lisboa: CNCDP, 2000); Ângela Domingues, "Para um melhor conhecimento dos domínios coloniais: a constituição de redes de informação no Império português em finais do Setecentos," História, Ciências, Saúde-Manguinhos 8 (2001): 823-38; Henrique Carneiro, "O saber fitoterápico indígena e os naturalistas europeus," Fronteiras 13, no. 23 (2011): 13-22; Juciene Apolinário, "Plantas nativas, indígenas coloniais: usos e apropriaçôes da flora da América portuguesa," in Usos e circulação de plantas no Brasil. Séculos XVI-XIX, ed. Lorelai Kury, 180-227 (Rio de Janeiro: Andrea Jakobsson Estúdio, 2013); Rafael Rogério Nascimento dos Santos, "Diz o indio...": politicas indígenas no Vale Amazônico (1777-1798) (Jundiaí: Paco Editorial, 2019). For expeditions carried out in the nineteenth century, see Carey McCormack, "Collection and Discovery: Indigenous Guides and Alfred Russel Wallace in Southeast Asia, 1854-1862," Journal of Indian Ocean World Studies 1 (2017): 110-27; Anderson Pereira Antunes, Luisa Massarani and Ildeu de Castro Moreira, "Practical Botanists and Zoologists': Contributions of Amazonian Natives to Natural History Expeditions (1846-1865),” Historia Critica 73 (2019): 137-60. 
[Willd. ex A. Juss.] Müll. Arg.). Throughout the centuries, that process involved multiple agents, from Amerindians to bankers, including missionaries, naturalists, colonial authorities, entrepreneurs and military personnel—and it was not without conflict and violence. ${ }^{7}$ However, there is a multitude of other Amazonian species, mainly edible and medicinal plants, whose appropriation process can be investigated within an agenda that questions specific topics, such as the indigenous role (and its elision) in the multicultural and transnational network that operated and operates the globalization of plants, the intertextuality in the representation of species, and the reframing that occurs during this process through the translation/transference of knowledge and the addition of new information layers.

Both points will be addressed in the next pages. The first aims at highlighting the indigenous protagonism in the exploration and inventory of the natural world by colonial enterprises in the second half of the eighteenth century. We start from the assumption that indigenous peoples are still eclipsed in the historiography of the production and circulation of knowledge, despite being currently acknowledged as historical agents. ${ }^{8}$ In other words, as individuals who had and still have their own agenda, who performed and perform according to their own perception of the universe that surrounds them. Thus, our intention is to give visibility to these subjects to prevent them from being overlooked and side-lined in the historical narrative. This is what happens in most studies about the philosophical travel of Alexandre Rodrigues Ferreira, for instance, in which little or no importance at all is given to Cipriano Sousa and José da Silva, both indigenous who helped in carrying out essential tasks, such as the collection and preparation of samples to be shipped to Lisbon. These men stood out among the assistants in the expedition, since they were promoted to alferes (ensign) of their own villages for their work with Ferreira, and they even moved to Portugal. ${ }^{9}$

The second topic has a different scale and an extended timeframe. It shows the extent to which indigenous peoples actively participated in the system that gathered colonial authorities and

\footnotetext{
${ }^{7}$ Lucile H. Brockway, Science and Colonial Expansion: The Role of the British Royal Botanic Gardens (New York: Academic Press, 1979); Barbara Weinstein, The Amazon Rubber Boom 1850-1920 (Baltimore: The Johns Hopkins University Press, 1985); Warren Dean, Brazil and the Struggle for Rubber: A Study in Environmental History (Cambridge: Cambridge University Press, 1987); Mauricio Nieto Olarte, Remedios para el imperio: Historia natural y la apropiación del Nuevo Mundo (Bogotá: Universidad de Los Andes, 2006); Neil Safier, Measuring the New World: Enlightenment Science and South America (Chicago: The University of Chicago Press, 2008); Eran Pichersky, Plants and Human Conflict (Boca Raton, Florida: CRC Press, 2018).

8 Manuela Carneiro da Cunha, ed., História dos Índios no Brasil (São Paulo: Companhia das Letras, Secretaria Municipal de Cultura, FAPESP, 1992); John Monteiro, Negros da Terra: Indios e bandeirantes nas origens de São Paulo (São Paulo: Companhia das Letras, 1994); Maria Regina Celestino de Almeida, Os indios na história do Brasil (Rio de Janeiro: FGV, 2010).

9 Osvaldo Rodrigues da Cunha, O naturalista Alexandre Rodrigues Ferreira: uma análise comparativa de sua Viagem Filosófica (1783-1793) pela Amazônia e Mato Grosso com a de outros naturalistas posteriores (Belém: MPEG, 1991).
} 
naturalists, both in the Americas and other continents. This connection, by which specimens and knowledge flowed, was fundamental for the inventory and exploration of the natural world. This process was marked by internal colonial dynamics, as portrayed by traditional historiography, but also by international and global relations more difficult to perceive without an integrated view and without crossing sources of different nature. This is our intention when we analyse the case of the ayapana herb (Ayapana triplinervis [Vahl] R.M. King \& H. Rob.), an Amazon-native plant that was incorporated into the pharmacological repertoire of local colonial society in the 1780s and, later, globalized by distinct international circuits of specimens and knowledge appropriation.

\section{Indigenous peoples and the production of knowledge about plants in the eighteenth century}

The centrality of indigenous peoples is clear in an economy such as that of colonial Grão-Pará, mostly regarding the collecting of drogas do sertão (drugs of the hinterland), cocoa cultivation and wood extraction for building ships and civil and military constructions, including the regular supply to royal palaces, farms, and pantries. ${ }^{10}$ The indigenous peoples were those who moved this world. The environment in which the plant species occur, the time of the year in which they bear fruit, the soils in which they can be cultivated, the resistance and durability of the wood, fibres and resins, the use as food, medicine and in rituals, the best processing, packaging, and transport techniques — in short, the immeasurable knowledge associated with hundreds or thousands of species of plants and animals—-were exploited by Portuguese settlers early on.

Examples of indigenous protagonism in the colonial economy are found in abundance, particularly after the enactment of the Diretório dos Indios (Indigenous Directory), regulation from 1757 that turned the old missionary settlements into villages that were governed by laypeople, who were sometimes elected from the indigenous population, in addition to the standardization of the use of native workforce. ${ }^{11}$ Twenty years later, when missionaries had already been banished, a document shows the natives from the villages of Faro and Alenquer fully organized for the collection and processing of drogas do sertão. On December 31, 1777,

\footnotetext{
${ }^{10}$ We use sertão in the sense of the eighteenth century. This word roughly meant the hinterland region, far from the coast. Drogas do sertão was the term used to designate plants of economic interest (medicinal and edible) collected in the forest.

${ }^{11}$ Mauro Cezar Coelho, "Do sertão para o mar: um estudo sobre a experiência portuguesa na América, a partir da Colônia-o caso do Diretório dos Índios (1751-1798).” (PhD diss., Universidade de São Paulo, 2005); Patrícia Melo Sampaio, Espelhos partidos: etnia, legislação e desigualdade na Colônia (Manaus: Universidade Federal do Amazonas, 2011); Fátima Martins Lopes, "Em nome da liberdade: as vilas de índios do Rio Grande do Norte sob o Diretório Pombalino no século XVIII.” (PhD diss., Universidade Federal de Pernambuco, 2005).
} 
they demanded from the Secretary of State for Kingdom Affairs, Tomás Xavier de Lima Vasconcelos, authorization to send to Lisbon, through ships belonging to the General Company of Grão-Pará and Maranhão, 74 arrobas and 26 arráteis (ca. 1.1 tons) of sarsaparilla, a vine whose roots had antisyphilis, anti-rheumatism and diuretic properties, transported in bundles tied in straw baskets, and 90 canadas (126 litres) of copaiba oil, extracted from the trunk of a tree and transported in barrels, and which had anti-inflammatory properties. Natives had been collecting and processing these medicinal plants for a long time, but now they were doing it on a larger scale, considering the production of the previous decade, and kept regular contact with the colonial authorities without missionary intermediation. ${ }^{12}$

The sources show the extraction of another product widely associated with natives: cravo-daterra (bark-clove), which was used as a spice, similar to the eastern product, and also as antiinflammatory when prepared as medicine. On September 26, 1780, 24 Amerindians, whose names are listed on a roster and lived in a place called Azevedo, on the Tocantins River basin, claimed their stipends by means of administrative instances of the government of Grão-Pará. They claimed they had not been paid for the job carried out in July 1775, when they were hired by the cabo de canoa (canoe captain) Francisco da Silva and the village director Manoel $\mathrm{da}$ Cruz to collect and process cloves. ${ }^{13}$ At that time, they collected 9 arrobas and 24 libras (ca. 146 kilos) of cravo fino (thin clove), 51 arrobas and 28 libras (ca. 778 kilos) of cravo grosso (thick clove), as well as 19 arrobas and 28 libras (ca. 298 kilos) of brown kapok. ${ }^{14}$

Clove was one of the Amazonian plants Europeans coveted the most since the seventeenth century, and countless expeditions were organized to collect it. ${ }^{15}$ Father João Felipe Bettendorff,

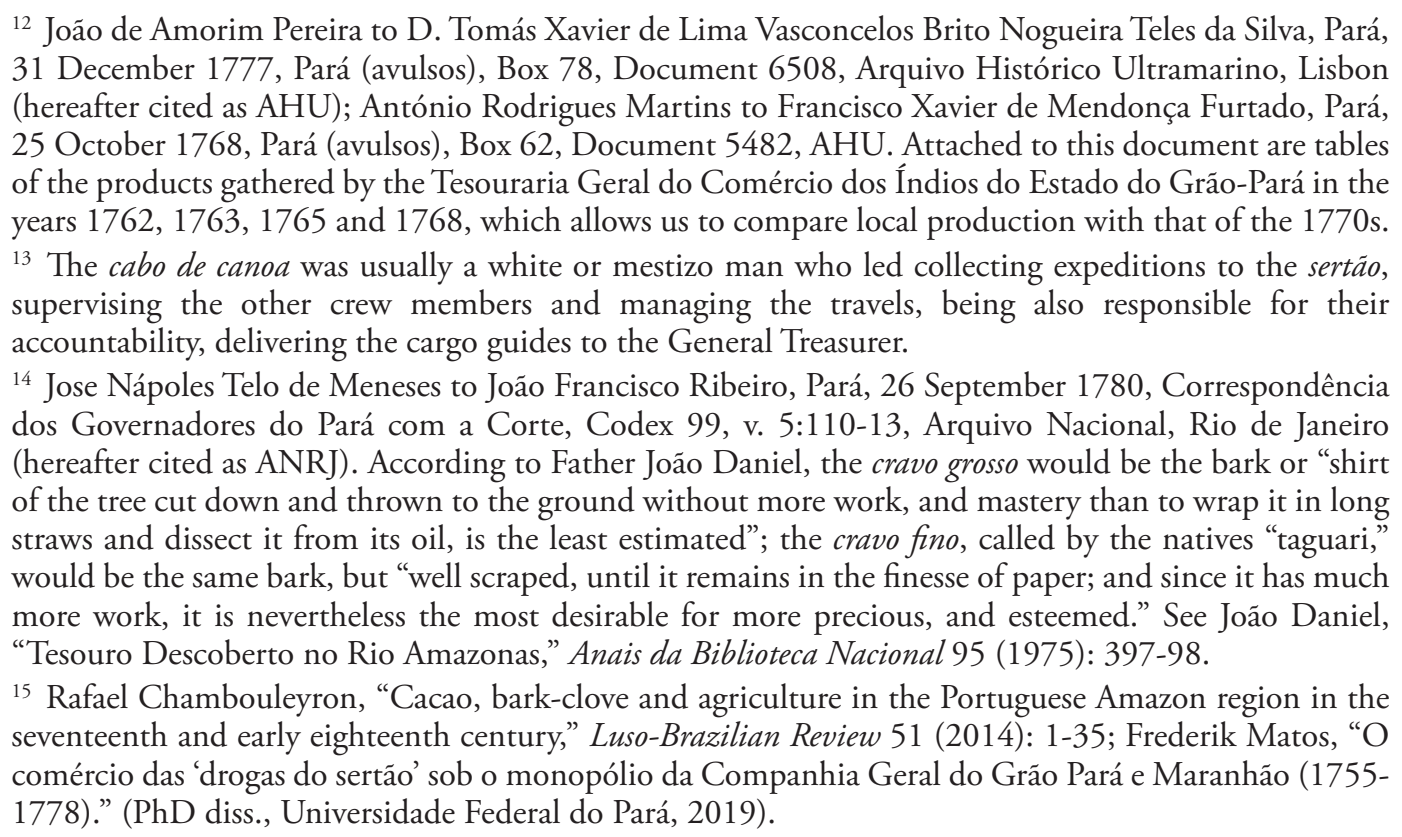


Superior of the Jesuits in Maranhão and Grão-Pará, when addressing the incursions taking place in the Xingu River region, where the plant occurred in abundance, named these expedition organizers cravistas, individuals who "risk themselves to get cloves wherever they are." The trips were made in boats "guided by highly experienced [indigenous] pilots," since the risk of shipwrecking in the river rapids was high, and they depended on experienced oarsmen, who were also natives. ${ }^{16}$ Furthermore, Amerindians were the ones indicating the location of the largest concentrations of clove trees, as testified by Father João Daniel, another Jesuit who lived in the region. According to his statement, missionaries were regularly informed about the existence of the plant close to the villages. He also described how the product was extracted: while in India they use the flower of the local species, in the Amazon, "they only get the bark of the trees and not the flower, which they discard . . . and to strip off their bark, they cut down the trees, of which there is a very sharp decrease in number ... and the same will happen to the others, unless something is done regarding their extraction from forests and rivers, where they are still found in abundance." ${ }^{17}$

The indigenous dominance over plant production can be highlighted in more than one example, this time regarding the production of resins. On April 23, 1781, governor José Nápoles Telo de Menezes sent to Lisbon a sample of a product he saw as new, cashew gum, with which he came across after conducting a "continuous inquiry" among the natives on the "different products of this country." According to him, caju (cashew) in the indigenous language means "fruit with seed that you eat" and produced a "useful and extremely perfect Gum or Resin," very similar to Arabic gum, which was often used in the "Ministry of Books." Bookbinders had already acknowledged "the perfect work" cashew gum did, besides its great usefulness for preserving the books against "the bug that quickly eats the binding of books coming from Europe." The gum was so strong that natives even used it as wood glue "with remarkable firmness and security." 18

Telo de Menezes mentioned neither where the resin was produced nor who produced it but saw it as a commodity of great abundance. For that reason, cashew gum could yield gains to the public Treasury, if it was commercialized-as actually happened. Shipments of cashew gum from Belém to Lisbon became frequent until the 1790s, thus indicating that not only was there a market for the product in the publishing sector, but that the resin had also adjusted to the demands of the market, and the local production — carried out by Amerindians with native technology—had been to some extent organized to meet external demand. Alexandre

\footnotetext{
${ }^{16}$ João Felipe Bettendorff, Crônica da missão dos Padres da Companhia de Jesus no Maranhão (Belém: SECULT, 1990 [1698]), 315.

17 Daniel, “Tesouro Descoberto no Rio Amazonas," 397.

18 José Nápoles Telo de Meneses to Martinho de Melo e Castro, Pará, 23 April 1781, Correspondência dos Governadores do Pará com a Corte, Codex 99, v. 3:39, ANRJ.
} 
Rodrigues Ferreira himself was entrusted to collect and ship resin samples, while preparing an inventory on the Amazon basin. ${ }^{19}$

Another agricultural and industrial development that required from indigenous peoples the appropriation and adjustment of cultivation and processing techniques was the dying industry, particularly that of indigo. This bluish dye was extracted from the leaves of bushes belonging to the Indigofera L. genus and has been known to Europeans from ancient times, in addition to being vastly commercialized by the Italian cities that were connected to eastern routes, and later by the Portuguese, French and Dutchmen. In the seventeenth and eighteenth centuries, the Portuguese tried to produce it in Brazil and Grão-Pará, but from America-native plants. ${ }^{20}$ For example, on February 16, 1784, the commander of the Fortress of São José, Manuel da Gama Lobo D'Almada, sent to governor Martinho de Sousa e Albuquerque the request of a chief surgeon named Juliāo Alves da Costa, asking for the assistance of 30 Amerindians to cultivate indigo and establish a single indigo factory in Macapá. ${ }^{21}$ This case, in an exploratory exercise, gives an idea of the number of Amerindians involved in indigo production in the Amazon basin at the end of eighteenth century, considering the news from Alexandre Rodrigues Ferreira about several similar factories established in the regions of the Negro River, lower Amazon, Tocantins River, Belém and surrounding areas.

The active involvement of indigenous peoples in indigo production can be seen in a list with the name of every producer established on the Negro River and the amount of dye produced by each one of them, sent by the governor of Gráo-Pará to minister Martinho de Melo e Castro on March 12, 1788. Among these producers, there is an Amerindian with the rank of Sergeant-Major, Joaquim de Oliveira, who produced that year in the village of Tomar 3 arrateis (96 arrobas or roughly 1 ton and a half). ${ }^{22}$ The number of producers in that region and, particularly the Tomar company, which was managed by natives, show that several ethnic groups mastered the new agricultural and industrial technologies and were integrated into the

\footnotetext{
${ }^{19}$ Correspondência dos Governadores do Pará com a Corte, Codex 99, v. 7, 8, 10, 12, 16, ANRJ.

${ }^{20}$ Currently, 13 species of Indigofera L. are known to occur in Brazil, in all biomes (with the exception of the Pantanal). It is not possible to determine, for lack of specific studies, which species were used in different captaincies where indigo factories were implanted. See Silvia T. S. Miotto and João R. V. Iganci, "Indigofera," in Lista de Espécies da Flora do Brasil (Rio de Janeiro: Jardim Botânico do Rio de Janeiro, 2015), available at: http://floradobrasil.jbrj.gov.br/reflora/floradobrasil/FB22979; Dauril Alden, "The Growth and Decline of Indigo Production in Colonial Brazil: A Study in Comparative Economic History," The Journal of Economic History 25, no. 1 (1965): 35-60; Rafael Chambouleyron and Alírio Cardozo, "As cores da conquista: produtos tintórios e anil no Maranhão e Grão-Pará (século XVII),"Locus 20 (2014): 55-76.

${ }^{21}$ Manuel da Gama Lobo D’Almada to Martinho de Sousa e Albuquerque, Fortaleza de São José de Macapá, 16 February 1784, Correspondência dos Governadores do Pará com a Corte, Codex 99, v. 5:28, ANRJ.

${ }_{22}$ Martinho de Souza e Albuquerque to Martinho de Melo e Castro, Pará, 6 May 1788, Correspondência dos Governadores do Pará com a Corte, Codex 99, v. 9: 55-57, ANRJ.
} 
colonial production system. According to travel itineraries and journals back then, such as those by José Monteiro de Noronha (1768), Francisco Xavier Ribeiro de Sampaio (1775) and Alexandre Rodrigues Ferreira (1786), the old Bararoá Mission, turned into the village of Tomar in 1758, was inhabited by the Manao, Baré, Passé, Ajuaná (Yayuaná, Uayuana) and Guirina natives. $^{23}$

Indigenous peoples were equally involved in collecting, transporting, packaging, and shipping of products to museums and botanical gardens in the Kingdom. In the late eighteenth century, Luís Pereira da Cunha is one of the persons who appears most in the network of individuals who participated in those activities, as a local interlocutor of the Royal Cabinet of Natural History. He was responsible for shipping to Lisbon the products collected by Alexandre Rodrigues Ferreira, in Belém. The long lists he prepared were both statements about the colonial interest in Amazonian natural products and valuable records of indigenous knowledge about native plants. The most interesting list dates to August 13, 1787 and was prepared for shipping nine boxes containing fifty-two seedlings of fourteen species of edible, medicinal, wood and fibre producing plants, particularly palm trees, which were commonly used by the Amerindians. A tenth box was shipped with bunches of prickly dry fruit from six palm trees and other species, in addition to fibre and wood samples. The live plants included cocoa, coffee, muruci, passion fruit, embaúba, andiroba, umiri, tucumä, ubuçu, inajá, jupati and the palm tree urucuri, visibly marked since it bears edible fruit, whose juice was used "for drying the milk from rubber trees." ${ }^{24}$

Cunha's lists leave out how the products were obtained and who took part in organizing the material. It was limited to mentioning that the shipment had been requested by Ferreira. However, we can assume that the collection, planting, and packaging processes of all materials were not carried out without the work of indigenous people. They probably selected and planted the seeds, cared for seedlings, dried the fruit, prepared the samples and boxes with dirt, in addition to indicating the use of everything Cunha shipped to the Royal Cabinet.

While Ferreira was in Grão-Pará, he personally supervised those shipments, activated the network of indigenous collaborators and local authorities, made the decision about what and when goods were to be shipped, with the support from his representatives in Belém. For

${ }^{23}$ José Monteiro de Noronha, Roteiro da Viagem da Cidade do Pará, até as últimas colônias do Sertão da Província (Pará: Typographia de Santos \& Irmãos, 1862); Francisco Xavier Ribeiro de Sampaio, Diário da viagem que em visita, e correição das povoaçóes da Capitania de S. Joze do Rio Negro fezo Ouvidor, e Intendente Geral da mesma Francisco Xavier Ribeiro de Sampaio no Anno de 1774 e 1775 (Lisboa: Typographia da Academia, 1825); Alexandre Rodrigues Ferreira, Diário da Viagem ao Rio Negro (Manaus: EDUA, 2007).

${ }^{24}$ Relação das plantas vivas que remete para o Real Gabinete da cidade do Pará, Luís Pereira da Cunha, Pará, 13 August 1787, Codex 99, v. 8:143-45, ANRJ. See also Luís Pereira da Cunha to Martinho de Melo e Castro, Pará, 13 August 1787, Pará (avulsos), Box 96, Document 7665, AHU. 
instance, on February 6, 1792, he wrote a detailed report on his explorations, collections, and shipments in the captaincy of Mato Grosso. This document is particularly interesting, since, in it, Ferreira criticized the abuse committed by village directors, who ruled as if they owned the trading posts, and praised the "freedom" granted to the natives, who were "free to apply for their own benefit the fatigues that, so far, had been employed for the benefit of others." In the document, it is possible to notice that Ferreira had considered several settlements as centres for obtaining local specimens and conducting agricultural experiments, in addition to seeking to establish collaborators to oversee the collection, cultivation and shipment processes in each settlement, perhaps the reason why he faced so many conflicts with some directors. ${ }^{25}$

After he returned to the Kingdom in late 1792, Ferreira made use of this same network to continue receiving plant and animal specimens intended for the Royal Cabinet and Botanical Garden of Ajuda. This is where indigenous participation in the collection process and agricultural development is the clearest, as can be seen in a letter from the governor of Grão-Pará dated February 14, 1793. Along with it, D. Francisco de Souza Coutinho sent to Lisbon a crate with achiote produced in Santarém, just like the one Ferreira had taken with him and the "first product of the Plantation, which I ordered to be made in all Indigenous Settlements, where the terrain allowed it." Once delivered, the product should be forwarded for proper "examinations that are to be conducted about its quality and about improvements the manufacturing process needs to have made to it." Coutinho also informed that he had recommended to all village directors and cabos de canoa, "who go upstream to the trade in the sertão," to transport to Belém animals, plants, minerals and "everything that was found, mainly the Jaguar, Monkey, Parrot or Macaw, which are not worth the shipping expense but have their usefulness because they sell easily." ${ }^{26}$ In this way, by guaranteeing the purchase of these specimens, Coutinho ensured the supply of the Royal Cabinet and the Botanical Garden, even after Ferreira's departure.

The local network for collecting, growing, and transporting products and specimens is made even clearer in another and final example. On September 12, 1795, a little over two years after Ferreira arrived in Portugal, the Secretary of State for Marine Affairs and Overseas Domains issued a notification ordering the governor of Grão-Pará to send to the Botanical Garden of Ajuda several live plants that were indicated in a list signed by Vandelli. On this list, 17 palm species were sorted in alphabetical order, some of them with their place of origin identified, such as the "Piassaba do Rio Negro"; other 31 species were identified as "Fruit trees and shrubs," some exotic ones among them, such as coffee and rose-apple; 29 species were identified as "Wild trees and shrubs," including fruit, wood, medicinal and aromatic plants, in addition

\footnotetext{
${ }^{25}$ Alexandre Rodrigues Ferreira to Martinho de Melo e Castro, Pará, 6 February 1792, Pará (avulsos), Box 101, Document 8035, AHU.

${ }^{26}$ Francisco de Souza Coutinho to Martinho de Melo e Castro, Pará, 14 February 1793, Correspondência dos Governadores do Pará com a Corte, Codex 99, v. 14:283, ANRJ.
} 
to a species that had already caught the attention of Europeans, the rubber tree; and 22 other unclassified species were listed, but it is possible to identify them as edible and medicinal plants, since they include peppers, manioc and other tubers, sarsaparilla and ayapana herb, the latter used as an anti-inflammatory for swelling and wounds. The order established that the plants were to be shipped in "crates full of the native dirt from which they were removed," that while at seas, they should be protected from the cold, should they travel during winter, and watered, should they travel during summer. At least three specimens of each species should be shipped. ${ }^{27}$

Although the list was signed by Vandelli, it is reasonable to assume that it had been prepared by Ferreira because of the number of species listed and the level of detail. Only he could know the native names of so many plants, most of them unknown to Europeans and that had yet to be scientifically described, occurring from the Negro River to Marajó Island. Furthermore, the way the list was organized, with species classified into categories, such as "Fruit trees and shrubs" and "Wild trees and shrubs," leads one to assume that domesticated and cultivated plants belonged to the first category, while the second included those whose access was difficult and those that were impossible to cultivate and grew only in forests. This basic division shows how important small farms and backyards in urban and peripheral areas are for the domestication and cultivation of native species, since they were sites for experimentation and had received considerable attention from urbanization projects that had been planned since the Pombaline consulate. ${ }^{28}$ In this plant appropriation and domestication process, a complex knowledge about varieties, characteristics and transplantation techniques among different environments was mobilized. It was essential for developing agricultural practices and the use of plants in cooking, medicine, and industry. ${ }^{29}$ Ferreira thoroughly described and analysed these practices and uses in several texts written during his travel, showing great interest in plants cultivated in backyards and small farms, in addition to the natural environments in which they occur, thus reinforcing the assumption that the list was written by him. ${ }^{30}$

27 Francisco de Souza Coutinho to João de Amaral Coutinho, Pará, 15 February 1796, Codex 471, Document 11, Arquivo Público do Estado do Pará, Belém. Attached to this document is the "Relação das plantas que se devem remeter vivas da Capitania do Pará para o Real Jardim Botânico," dated September 12, 1795.

${ }_{28}$ Renata Malcher Araújo, As Cidades da Amazónia no Século XVIII. Belém, Macapá e Mazagão (Porto: FAUP, 1998); Nestor Goulart Reis Filho, Imagens de Vilas e Cidades do Brasil Colonial (São Paulo: EDUSP/IOE/FAPESP, 2000).

29 Ermelinda Pataca, "Coleta, transporte e aclimatação de plantas no Império Luso-Brasileiro (17771822)," Revista Museologia \& Interdisciplinaridade 5 (2016): 88-108; Ermelinda Pataca, "Entre a engenharia militar e a arquitetura médica: representaçóes de Alexandre Rodrigues Ferreira sobre a cidade de Belém no final do século XVIII," História, Ciências, Saúde-Manguinhos 25 (2018): 89-113.

30 See, for example, two memoirs written by the naturalist shortly after arriving in Belém: Alexandre Rodrigues Ferreira, "Miscelânea histórica para servir de explicação ao prospecto da cidade de Belém do Grão-Pará,” Pará, 8 September 1784, Lata 282, Livro 7, Instituto Histórico e Geográfico Brasileiro, Rio de Janeiro, and Alexandre Rodrigues Ferreira, "Estado presente da Agricultura no Pará," 1784, Seção de Manuscritos, Codex 21, 1, 6, Biblioteca Nacional, Rio de Janeiro. 
Upon receiving the document on February 15, 1796, Coutinho revealed the indigenous centrality in this inventory of natural resources: he forwarded the letter to João de Amaral Coutinho, the General Treasurer of Indigenous Trade, requesting the application of "all diligence ... to make ready alive and with the brevity and economy needed ... all the plants sorted on the list" João Coutinho was certainly the authority able to identify where each of those plants should be collected or where they were cultivated, across the several settlements he administrated in the State of Grão-Pará and Rio Negro. From Belém, the list was copied and sent to many directors, along different basins, since some of the species listed were endemic to the Negro River or Xingu River, for instance. At the edge of this network, it would be possible to see Amerindians identifying the plants and preparing the boxes with the seedlings requested by naturalists residing on the other side of the Atlantic.

These invisible agents of science are rarely mentioned as an important part of complex networks that moved knowledge, specimens, and products, including goods of commercial interest, and that integrated not only literate subjects such as naturalists and missionaries, but also colonial agents of various degrees, such as governors, directors, captains and cabos de canoa. This extraordinarily weaved mesh, covering a highly diverse set of social groups, helps to understand how the circulation of knowledge in the Amazonian world occurred. That mesh covered an extensive territory and functioned over the long term. It required moving across the sertôes and a unique knowledge about every environment, as well as combining extractive practices with agricultural production carried out close to urban centres. Indigenous peoples were important players in this mesh, not only as workforce, a category to which they are often (and simply) reduced, but as sources of knowledge and producers of technologies, without whom the dissemination of information and of native species would have not been possible.

In the next section, we will address the specific and poorly known case of the ayapana herb, with the objective of recovering the globalization process of a plant species native to the Amazon, whose uses clearly originate in local indigenous cultures. This case is very well documented in the sources. It illustrates how colonial dynamics are associated with broader international processes; how the natives of this region were connected to heterogeneous networks, which operated with a common interest in the natural world; and how the original knowledge is elided in the globalization process, as new layers of information are added to the plant in question.

\section{The globalization of ayapana and the elision of indigenous knowledge}

A good example of indigenous knowledge and practice appropriation by colonial society is a report made by Alexandre Rodrigues Ferreira to the governor of Grão-Pará on March 15, 
1784. A few months after arriving in Belém, Ferreira reported that he had observed in the city's backyards a plant named ayapana, which he claimed was a new species of Eupatorium, genus created by Carl von Linnaeus in 1753 to designate a group of herbs that were native to the American continent. ${ }^{31}$ However, the fact that it was a new species, in other words, not yet scientifically named or described by botanists, was not the main topic in the document. Instead, Ferreira highlighted the news that the population was "experimenting" (this is the verb he used) with ayapana as the "strongest antidote against snake venom." When the herb arrived in the city, the first person to conduct experiments with it was physician Bento Vieira Gomes. ${ }^{32}$

Ferreira neither revealed his sources of information nor did he give details on the experiments Gomes was conducting, but he investigated the plant's origin and how it should be used. According to him, it was taken from the sertão to the city by cabo de canoa Álvaro Sanches de Brito, who, in turn came across it via "a Savage, his Mistress." This woman, whose name, ethnicity, and place of residence were not revealed, supposedly got specimens of the plant and gave them to her lover. The three-page story told by Ferreira has burlesque tones: upon learning about the uses of the plant, Brito requested a specimen from his indigenous lover, who, in turn, denied by saying that her relatives would kill her should they find out that she had given or revealed to him the plant that was able to cure snake bites, stingray stings, insect bites and even the terrible wounds caused by poisoned arrows. However, the young woman, for love, promised Brito a specimen if he took her to Belém with him. Both held their part of the bargain and ayapana seedlings were transported by canoe in a basket with dirt.

When they arrived in town, the ouvidor-geral (higher authority of justice in the colony) Matias José Ribeiro was notified of the "discovery" and ordered the seedlings to be distributed to "curious" individuals to cultivate them. Different experiments were conducted by the residents, who used animals and enslaved people as well as various recipes. Later, the ouvidor-geral sent the plant to Lisbon "with the list of its virtues." Those qualities led Belem's Portuguese residents to name it "miracle herb," "counter herb" or, obligingly, erva-do-ouvidor (ouvidor herb).

Ferreira did not tell when the ayapana was "discovered," however, when he mentioned Gomes and Ribeiro, he hinted at the moment when the process of appropriation of the plant and

\footnotetext{
${ }^{31}$ It is not possible to determine if the plant Ferreira claimed to have observed did actually belong to this genus. However, the genus is still valid and currently gathers about 600 described species, of which 250 are found in Brazil, many of them with scientifically proven medicinal properties. See Carl von Linnaeus, Species Plantarum (Holmiae: Imprensis Laurentii Salvii, 1753), v. 2: 836; Robert Merrill King and Harold Ernest Robinson, The genera of the Eupatorieae (Asteraceae) (St. Louis: Missouri Botanical Garden, 1987).

32 Report of the naturalist Alexandre Rodrigues Ferreira to the governor and captain general of the State of Grão-Pará and Rio Negro, Martinho de Sousa e Albuquerque and for the Secretário de Estado da Marinha e Ultramar, Martinho de Melo e Castro, Pará, 20 April 1786, Pará (avulsos), Box 95, Document 7559, AHU.
} 
the knowledge associated with it by colonial society began. Concerning Gomes, it is known that he had graduated from the University of Coimbra and worked as Chief Physicist in the State of Grão Pará and Rio Negro, starting in $1783 .{ }^{33}$ This was certainly the reason why he was mentioned by Ferreira, since Gomes was in charge of verifying the quality and efficacy of the medicine, managing the population's health and inspecting other healing practices. ${ }^{34}$ Concerning Ribeiro, there are plenty of sources: he had been appointed juiz-de-fora (local judge) and Royal Treasury manager in the city of Belém, on September 19, 1772. ${ }^{35}$ In 1780, he also took on the position of ouvidor-geral, one of the most important positions in colonial administration, the main person in charge of the legal orders applied in the colony. ${ }^{36}$ In 1782, he took on another position, that of general administrator of trade, agriculture and manufactures of Grão-Pará. Thus, he was one of the most powerful employees of the Crown in the State. He was in charge of judicial decisions, treasury administration, royal assets and rights, surveys in the settlements, mapping the villages governed by the Diretório dos Índios, as well as inspecting the various goods arriving at the Customs of Belém and leaving for Lisbon. This clarifies the time when ayapana was introduced in the city-between 1780 and 1783-as well as the reason why Ribeiro, possibly Ferreira's informant, was another central subject in the history reported here.

The process by which a medicinal plant known to indigenous peoples, commonly identified by a Tupi name, became the erva-do-ouvidor was relatively common in many colonial experiences. ${ }^{37}$ On those occasions, the participation of the local population in the production of knowledge is either omitted or mocked, as we have seen in the case reported by Ferreira. He recorded no data on the origins of the woman who obtained the seedlings, but he described twice how she had circumvented her own people's recommendation to keep the knowledge of the plant a secret. Thus, instead of the indigenous peoples, a cabo de canoa who knew how to seduce an

${ }^{33}$ On the appointment of Bento Vieira Gomes to the post of Físico-Mor (Chief Physicist), see Martinho de Melo e Castro to Martinho de Sousa e Albuquerque, Lisbon, 1 August 1783, Pará (avulsos), Box 90, Document 7320, AHU. See also Bento Vieira Gomes to the Queen D. Maria I (requesting freedom to transit throughout the Kingdom), Pará, 15 October 1777, Pará (avulsos), Box 78, Document 6469, AHU; and Bento Vieira Gomes to the Queen D. Maria I (requesting the Hábito das Ordens Militares), Lisbon, 30 June 1797, Ministério do Reino, Pack 685, Process 4, Arquivo Nacional da Torre do Tombo, Lisbon.

${ }^{34}$ Regimento que serve de lei, que devem observar os comissários delegados do Físico mor do Reino no Estado do Brasil, Lisbon, 1744, Codex 314, ANRJ.

${ }^{35}$ Decree of King D. José I [appointing Francisco José Antonio Damásio and Matias José Ribeiro, 19 September 1772], Box 66, Document 5883, AHU.

${ }^{36}$ Decree of Queen D. Maria I [appointing José Ribeiro, 3 November 1780], Box 86, Document 7066, AHU.

${ }^{37}$ Christopher Parsons, "Plants and Peoples: French and Indigenous Botanical Knowledges in Colonial North America, 1600-1760." (PhD diss., University of Toronto, 2011); Alix Cooper, Inventing the Indigenous: Local Knowledge and Natural History in Early Modern Europe (Cambridge: Cambridge University Press, 2007). 
indigenous woman appears as the author of the "discovery" and, as benefactor of humanity, a colonial authority was honoured with his very name given to a plant. This is a real case of elision of local knowledge, a phenomenon to which many researchers from different fields and theoretical approaches draw attention. ${ }^{38}$

The case is emblematic because the appropriation of indigenous knowledge is well documented, and Ferreira's narrative can be deconstructed. It is possible to follow part of the path taken by the herb while in the hands of the cabo de canoa, that of the ouvidor-geral, the physician and the naturalist, the path in which the appropriation and translation of the knowledge took place, but the ethnicity of the woman who provided the plant or the place from which it was collected was overlooked. This makes an ethnobotanical analysis impossible, although the plant soon became one of the most used anti-inflammatory medicines in Grão-Pará. For instance, in the "Ensaio Corográfico" (Chorographic Essay), by military engineer Antônio Ladislau Monteiro Baena, who was transferred to Belém in 1803, the ayapana emerges among the local plants that were "pleasing not only to the sight, but to the man's sense of smell and palate as well, which ordinary curiosity might find, or an official chance might encounter." Baena defines it as "the aromatic herb used to heal certain wounds" and also for the treatment of earache, by mixing it with "breast milk." 39

If we assume that Alexandre Rodrigues Ferreira was actually referring to this species in his 1784 report to the governor of Grão-Pará, we can also accept that he was correct when stating that it was a plant unknown to science that, back then, could be classified as belonging to the Eupatorium genus. In 1794, a little over ten years after the plant was revealed to the Portuguese authorities in Belém, the Norwegian naturalist Martin Henrichsen Vahl described the ayapana as Eupatorium triplinerve. He based the name on a specimen sent from "Insula Santa Crucis" by "Dr. Pflug." ${ }^{40}$ According to the clues Vahl provided and to his professional trajectory, it is not hard to imagine how the plant reached his hands. Despite being Norwegian, Vahl built his career as a physician and naturalist at the university and botanical garden in Copenhagen, since Norway and Denmark were unified under the same dynasty, thus making it possible for professionals to transit between both countries. ${ }^{41}$ His book, Symbolae botanicae, was dedicated

${ }_{38}$ Mary Louise Pratt, Imperial Eyes: Travel Writing and Transculturation (London: Routledge, 1992); Michael T. Bravo, "Ethnological encounters," in Cultures of Natural History, ed. Nicholas Jardine, James Secord and Emma Spary, 338-56 (Cambridge: Cambridge University Press, 1996); Londa Schiebinger, Plants and Empire: Colonial Bioprospecting in the Atlantic World (Cambridge, MA: Harvard University Press, 2007).

39 António Ladislau Monteiro Baena, Ensaio corográfico sobre a Província do Pará (Belém: Typographia de Santos \& menor, 1839), 34-5, 72.

${ }^{40}$ Martin H. Vahl, Symbolae botanicae, sive plantarum, tam earum, quas in itinere, imprimis orientali. (Hauniae [Kopenhagen]: Excudebant Nicolaus Möller et Fillius, 1794), part 3, 97.

41 Per M. Jørgensen, "Martin Vahl (1749-1804)-den første norske botanikkprofessor," Blyttia Norsk Botanisk Forenings 2 (1999): 52-60. 
to regent Frederico (future Frederico VI of Denmark) and included mostly species sent to him from the colonial world, including Saint Croix. This Caribbean island, which nowadays is part of the United States Virgin Islands, was bought from France by the Danish West India and Guinea Company in $1733 .{ }^{42}$ There, the Company established a botanical garden, which gathered Caribbean species and those from different tropical colonies, including Grão-Pará, Brazil and Isle de France (currently named Mauritius) — many of them described in the book mentioned.

It is hard to track how the ayapana arrived in Saint Croix without further investigating Danish sources, which has not been possible so far. However, it can be stated that the plant is not native from the Antilles, since Vahl himself informed that it was a species that had been introduced into the botanical garden. Thus, the Grão-Pará, Saint Croix and Copenhagen itinerary was certainly the second one to favour the globalization of the ayapana, after the plant was sent from Belém to Lisbon in the 1780s, and in subsequent shipments, as seen in the request made by Vandelli in 1795 .

It is possible to identify in the sources the other international itineraries that made the ayapana known worldwide. For instance, on September 1, 1802, the botanist Étienne Pierre Ventenat held a conference at the National Institute of France about the ayapana. He was in charge of the garden of Château de Malmaison, which belonged to Joséphine de Beauharnais, Napoleon Bonaparte's wife. According to him, the plant grew on the right margin of the Amazon river, and was used by the local inhabitants as a "great sudorific," a "powerful alexipharmic or antidote against snake bites and poisoned arrow wounds," the reason why it was known as "miraculous plant." ${ }^{33}$ Ventenat goes on telling how the plant had reached his hands: in 1798, captain Augustin Baudin was passing by Brazil and heard of the "fabulous" ayapana from "Dr. Câmara." " 4 This was the physician who provided Baudin with some plants, so that they were introduced into the French colonies. Baudin kept them on his ship, but the chickens he was carrying destroyed them. Distressed by the loss, he looked for several residents, but his requests were not accepted, and his offers were rejected. Thus, he decided to do something different. According to Ventenat:

${ }^{42}$ Isaac Dookhan, A History of the Virgin Islands of the United States (Kingston, Jamaica: Canoe Press, 1974), 42-5.

43 Étienne Pierre Ventenat, "Note sur l'Aya-Pana," Magasin Encyclopédique 8, v. 3 (1802): 77.

44 Danielle Almeida identifies "Dr. Câmara" as the doctor and botanist Inácio Ferreira da Câmara Bittencourt, who at the time was living in Salvador. See Danielle Almeida, "O trato das plantas: os intermediários da cura e o comércio de drogas na América Portuguesa, 1750-1808." (PhD diss., Fundação Oswaldo Cruz, 2017), 217-18. 
The love for science and the desire to be useful to his country led him to ignore some considerations that would have otherwise stopped him. He remembered that there was an ayapana plant on the window of an individual who had consistently avoided him and planned on stealing it at night. He was accompanied by some sailors, who, with the help of long sticks tipped the pot in which the plant was. Captain Baudin grabbed it quickly, boarded and set sail to Isle de France as dusk approached. ${ }^{45}$

The heroic act was praised by Ventenat, because, thanks to Baudin, the plant successfully acclimated and reproduced at the Pamplemousses Royal Garden (currently named Sir Seewoosagur Ramgoolam Botanical Garden). On the Isle de France and Isle de Bourbon (currently named Isle de Réunion), the ayapana became equally known by its medicinal properties. ${ }^{46}$ Ventenat reports in detail several cases of people bitten by animals or affected by diseases who were cured by the ayapana; all cases were published in local newspapers and reported to the colonial authorities and naturalists in Paris. Seeds and seedlings were shipped to the capital, including to Joséphine de Beauharnais, who received them directly from the Pamplemousses administrator, Jean-Nicolas Céré. She introduced them into the gardens of her own castle, under the care of Ventenat.

The success of this experience allowed Ventenat to scientifically describe the plant and observe some of its therapeutic properties, along with some physicians from Saint Louis Hospital in Paris. The description appeared in another publication he himself created and directed with the sponsorship of Beauharnais, titled Jardin de la Malmaison (Garden of Malmaison). In the first volume, in 1803, the ayapana was classified as Eupatorium ayapana, currently synonymous with the species created by Vahl. ${ }^{47}$ Regardless of the loss of priority, Ventenat is seen as the first botanist to publish an illustration of the ayapana (Figure 1), painted by Pierre-Joseph Redouté, who was famous for his watercolours depicting flowers that were cultivated in Malmaison. ${ }^{48}$ The quality of the work did not go unnoticed by Augustin Pyramus de Candolle, who regarded

45 Ventenat, "Note sur l'Aya-Pana," 78. In his text, Ventenat reproduces a memory that Baudin himself wrote about ayapana, recording the way he obtained it and the uses that were made of it in Brazil. This memory was sent from the Isle de France by Baudin to Antoine Laurent de Jussieu, then director of the National Museum of Natural History in Paris, who, in turn, passed it on to Ventenat. See Augustin Baudin, Mémoire sur l'aya-pana, le 20 frimaire an X (December 12, 1801), Catalogue de la vente de la bibliothèque de Jussieu, 1857, no. 3873, Document 192, Muséum national d'Histoire naturelle, Paris.

46 On the acclimatization of the plant on these Indian Ocean islands and local therapeutic uses, see Claude Alphonse Marodon, "Contribution à l'étude de Eupatorium ayapana Ventenat de l'Ile de La Réunion.” (PhD diss., Université Montpellier 1, 2011).

47 Étienne Pierre Ventenat, Jardin de La Malmaison (Paris: Imprimerie de Crapelet, 1803), engraving no. 3 .

${ }^{48}$ Martin Callmander, Pascal Martin, Hans Walter Lack and Laurent Gautier, "Etienne-Pierre Ventenat (1757-1808) and the Gardens of Cels and Empress Joséphine," Candollea 72, no. 1 (2017): 87-132. 
it as a reference in his classic botany manual, since it had been painted from a live plant which was unknown to Europeans and of which there was no other image. ${ }^{49}$

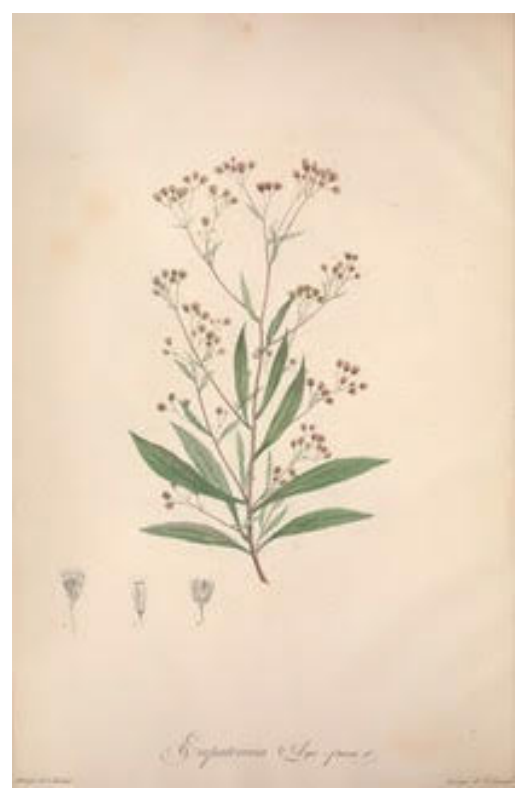

Figure 1. Engraving no. 3 of the first volume of Jardin de la Malmaison, by Étienne Pierre Ventenat, representing the Eupatorium Aya-pana species. Image from the Biodiversity Heritage Library, contributed by Smithsonian Libraries, www.biodiversitylibrary.org

Concerning the therapeutic properties of the ayapana, they were extensively tested in France. Ventenat wrote in his publications that the qualities attributed to the plant were widely exaggerated, both in Brazil and in Isle de France, but gave no further details. Only in 1816 did another French publication summarize what was already known about the "miraculous plant." It is the Dictionnaire des Sciences Naturelles (Dictionary of Natural Sciences), in which the "Ayapana" emerges as a three-page entry. ${ }^{50}$ It was written by Louis-Marie Aubert du Petit-Thouars, an expert in the flora of Madagascar and Isles de France and Bourbon where he lived in exile between 1792 and 1802.51 Petit-Thouars had already written something about the ayapana in his book Mélanges de botanique et de voyages (Mixtures of botany and travel), in which he mentioned the great popularity the plant had attained on Isle de France, and questioned the description made by Ventenat, despite agreeing with him that the Eupatorium genus did not

49 Augustin Pyramus de Candolle, Théorie élémentaire de la botanique; ou, Exposition des principes de la classification naturelle et de l'art de décrire et d'étudier les végétaux (Paris: Déterville, 1813), 276.

${ }^{50}$ Louis-Marie Aubert du Petit-Thouars, "Aya-pana," in Dictionnaire des Sciences Naturelles, ed. Frédéric Cuvier, v. 3, Supplement, 359-62 (Strasbourg: F. G. Levrault Éditeur, 1816).

${ }^{51}$ Louis-Marie Aubert du Petit-Thouars, Histoire de vegetaux recueillis dans les iles australes d'Afrique, Première partie (Paris: Tourneisen Fils, 1806), viii-ix. 
suit the species properly. ${ }^{52}$ In this work, he even published a second print of the plant, as an alternative representation to the one included by Ventenat in Jardin de la Malmaison.

In the note of Dictionnaire des Sciences Naturelles, Petit-Thouars resumed the issue of the taxonomic inconsistency of the plant and updated the heroic narrative about its introduction into the French colonies. Baudin remained as the main character in history, but Petit-Thouars took on the supporting role, meaning that he saw himself as one of the first to publish the "great properties" that were attributed to the plant, particularly in the French colonies of the Indian Ocean and India. At the beginning of the century, when he was still living in Isle de France, he published newspaper articles about the ayapana in Madras (currently named Chennai), thanks to his relationship with a local English doctor. This doctor was John Fleming, surgeon of the Bengal military unit, who, in 1810, published the Catalogue of Indian Medicinal Plants and Drugs, in which the ayapana emerges as one of the species cultivated in the botanical garden of Calcutta, possibly introduced from Isle de France..$^{53}$

Another source that attests the globalization process of the ayapana-and that does not depend on the itinerary established across the British and French colonies-are the letters written by Johann Centurius Hoffmann, earl of Hoffmannsegg. Hoffmann is mostly known for founding the Berlin Zoological Museum, but he also kept scientific relationships with literate Portuguese individuals. He travelled the Portuguese territory between 1795 and 1801, along with Johann Heinrich Friedrich Link. ${ }^{54}$ These travels resulted in a botanical collection and a book named Flore portugaise ou description de toutes les plantes qui croissent naturellement en Portugal (Portuguese flora or description of all the plants that grow naturally in Portugal) in addition to the authorization for Hoffmann's protégé, naturalist Friedrich Wilhelm Sieber, to travel to Grão-Pará and collect natural history specimens. The trip lasted four years, along the outskirts of Belém, Marajó Archipelago, Tocantins River, and lower Amazon region. This was one of the few expeditions carried out by a foreign naturalist on Portuguese territory in the colonial period authorized by the Crown..$^{55}$

Sieber got to Belém in September 1803. Just like Ferreira and Baudin, he was immediately surprised by the "miraculous herb," which in the form of tea and poultice would be able to heal a variety of maladies, such as dropsy, tetanus, and poisoning. Sieber immediately reported the

52 Louis-Marie Aubert du Petit-Thouars, Mélanges de botanique et de voyages (Paris: Arthus Bertrand Libraire, 1811), 73-6.

53 John Fleming, Catalogue of Indian Medicinal Plants and Drugs (Calcutta: Hindustani Press, 1810), 20-1.

${ }^{54}$ Nuno Gomes Oliveira, A Flore Portugaise e as Viagens em Portugal de Hoffmannsegg e Link (1795 a 1801) (Lisboa: Chiado Editora, 2015).

55 Anonymous, "Die wundersame Vermehrung der Sammlung Hoffmannsegg/Sieber," Kunst \& Kontext 17 (2019): 80-95; Lothar A. Beck, ed., Zoological Collections of Germany: The Animal Kingdom in its Amazing Plenty at Museums and Universities (Cham, Switzerland: Springer, 2018). 
remarkable qualities of the plant to his mentor, who, in turn, contacted D. Rodrigo de Souza Coutinho in Lisbon, so that Sieber received the authorization for transplanting the ayapana seedlings into European gardens, in order that mankind could benefit from its qualities. Concurrently, Hoffmann published the letter from Sieber, dated June 12, 1804, which ended up being reproduced in European scientific magazines. The Philosophical Magazine, edited in London was one of the first magazines to publish Sieber's personal experiments with the plant. According to him, a poultice with macerated leaves had saved him twice from "bites," first from a poisonous caterpillar and then from a centipede. ${ }^{56}$

This was undoubtedly another route taken by the ayapana that did not depend on what was recorded in Portuguese, Danish and French sources—and one that may have connected Belém, Lisbon and Berlin, with developments in England. It is worth pointing out that, while the ayapana was taking on the world, the plant's origin was being erased. None of the sources quoted here, except that from Ferreira's first report, mentioned the indigenous knowledge underlying the entire process. They refer only to uses "habitants from Brazil" or Isle de France attributed to it. In turn, new layers of information were added to the plant within the most diverse international itineraries including Portugal, Norway, Denmark, France, United Kingdom and Prussia. These empires connected metropolises and colonies located in Europe, South America, the Caribbean, Africa, and Asia.

In Paris, medical experiments had been conducted for quite some time, and resulted in adjustments to the therapy repertoire that was associated with the ayapana. According to PetitThouars' entry published in 1816, the plant could no longer be seen as an "universal panacea" able to cure any disease or malady, but it probably "could advantageously be used in different cases." Many "consecutive and repeated experiments by experts in the technique" were needed to attribute to the plant its "rightful place in medical matters." ${ }^{57}$ Jean-Louis Alibert (1768-1837), the main clinician at Saint Louis Hospital, mostly known for being one of the dermatology systematisers, had been conducting those experiments from the start. ${ }^{58} \mathrm{He}$ published the results only in 1826, and included the ayapana in the list of "new" plants that acted on the tonicity or "fibrillar contractility" of the stomach and intestines. His experiments aimed at "freeing it [the ayapana] from the vain apparatus of so many fabulous narratives with which we have already overloaded its history," particularly that of the belief that it was able to counterattack the poison of snakes, scorpions and "rabid dogs." According to Alibert, the antivenom properties of the ayapana had not been proven by the series of experiments he had conducted, but the

\footnotetext{
56 Anonymous, "Natural history," The Philosophical Magazine 21 (1805): 91-3.

57 Aubert du Petit-Thouars, "Aya-pana," 359-60.

58 Marianna Karamanou, Theodora Psaltopoulou, Gregory Tsoucalas and George Androutsos, "Baron Jean-Louis Alibert (1768-1837) and the first description of mycosis fungoides," Journal of the Balkan Union of Oncology 19, no. 2 (2014): 585-88.
} 
plant presented astringent properties and could be used as anti-inflammatory in swelling. In infusions, it would be "infinitely beneficial" against scurvy. ${ }^{59}$

In 1829, the pharmacist M. Waflart, about whom little is known, published a note that complemented Alibert's clinical analyses. He described in detail the procedure for manufacturing an ayapana extract from the decoction of leaves and analysed its essential chemical components, confirming its astringent and antispasmodic properties. He used in this experiment a "large amount of aya-pana" that he had received from a "person from Isle de France," where it was quite used against cholera, "maladie de poitrine" (angina) and indigestion. In the end, he recommended more detailed studies to be conducted about the plant, which seem to have effective therapeutic properties. ${ }^{60} \mathrm{It}$ is interesting to observe that a summary of Waflart's note was incorporated into the Italian translation of Dictionnaire des Sciences Naturelles, published in Florence in 1830. The publishers had inserted the summary as a new entry entitled "Ayapana," thus differentiating it from that by Petit-Thouars, since they were phytochemical and not botanical aspects. ${ }^{61}$

At this point, the ayapana seemed to have been incorporated into the universal pharmacopeia, not as enthusiastically as it had been publicized at the end of the eighteenth century and beginning of the nineteenth century, but with the necessary caution for a more accurate prescription, including in Brazil. This is what is deduced from the work of the physician Joseph François Xavier Sigaud, who was very influential in the country. After documenting the popular uses of the plant in Pernambuco, where it had been introduced in 1798, Sigaud recommended caution, since the plant's antivenom properties had yet to be confirmed by clinical studies. He included it in the list of aromatic plants with "stimulant" properties. ${ }^{62}$ Another source that was produced in the mid-nineteenth century in Brazil ponders on the same issues and opposes its popular uses and medical recommendations. It is a handwritten botanical dictionary that belonged to D. Pedro II which includes the entry "Ayapana." The unknown author, probably one of the mentors of Brazil's Emperor, had translated into Portuguese the plant's morphological description, reproduced part of Sieber's letter, that of Petit-Thouars' entry and Sigaud's observations. He also summarised the clinical and chemical analyses conducted by Alibert and Waflart, and added:

59 Jean-Louis Alibert, Nouveaux éléments de thérapeutique et de matière médicale, Tome 1 (Paris: Béchet Jeune, 1826): 159-63.

${ }^{60}$ M. Waflart, "Note sur l'aya-pana (famille des corymbifères)," Journal de Pharmacie et des Sciences Accessoires 15, no. 1 (1829): 8-10.

${ }^{61}$ Frédéric Cuvier, ed., Dizionario delle Scienze Naturali (Firenze: V. Batelli e Figli, 1830), tome 1, 301-2.

${ }^{62}$ In his book, Sigaud included a chapter entitled "Indian Diseases and Jesuit Medicine," in which he documents the medicinal uses that various indigenous peoples made of plants, including ayapana. According to Sigaud, this plant was used against tetanus. See Joseph François Xavier Sigaud, Du climat et des maladies du Brésil ou statistique médicale de cet empire (Paris: Chez Fortin, Masson et Cie, Libraires, 1844), 122, 435, 530 . 
In Brazil today, the ayapana plant is not often sought after, but does not deserve to be forgotten or misprized. On the contrary; the materia medica should accept it as a powerful resource for serious fevers, since it causes copious sweats and its aromatic flavour presents an antispasmodic property. The experiments of $\mathrm{Mr}$. Siébes [Sieber], naturalist sent to Brazil in the beginning of this Century, also need to be repeated. Dr. Siébes [Sieber] applied the fresh juice immediately on the bite, preventing suppuration from manifesting, causing inflammation and swelling to subside with this simple means. The recommendation from healers from the North provinces consists in ingesting the tea obtained from the leaves, while covering the wounds with stepped leaves placed under cloths moistened with a cooking laden with leaves. Many prepare the tea with two ounces of green leaves and one pound of boiling water; the mildly aromatic beverage has pleasing flavour, particularly when sugar and lemon juice are added. A purgative syrup, with no drastic effects, is obtained from the leaves. It is certain that when the Ayapana is drunk in large doses for serious fever, it causes profuse sweating and enteric dejections, which explains the wonders in the epidemic in Pernambuco and healing of monks of Olinda. Some physicians in today Genoa recommend the use of Ayapana tea rather than Indian tea, since it presents some qualities of the Chinese plant and develops tonka beans aroma, in addition to bitter flavour. Professor Alibert limited to recommending the use of infusion in mild scurvy issues. $^{63}$

It is important to realize that, in the excerpt above, the Amerindians re-emerge, although they are disqualified in the "healers [curandeiros] from the North provinces" sentence and are placed on a plane that is different from that of other individuals mentioned in the entry, such as "Dr. Siébes" (Sieber), the "monks from Olinda" and "professor Alibert." Thus, the ancestry and origin of the knowledge about the plant are not recognized, nor are the indigenous peoples acknowledged as being part of a transnational and multicultural chain that has taken place in the investigation of the therapeutic properties of ayapana.

After a first exploratory period, the stabilization of the therapeutic knowledge about the ayapana found its parallel within the taxonomic scope, thanks to the works by Édouard Spach, from the National Museum of Natural History in Paris. In 1841, aiming at solving the inconsistencies already revealed by Ventenat and Petit-Thouars, he created the Ayapana genus precisely because it includes the Ayapana officinalis species, replacing the name given by Vahl and Ventenat. According to Spach, the plant grew in Brazil and was used as "antidote against snake bite and as medicine against a series of diseases." ${ }^{\prime 4}$ The taxonomic highlight the plant received

${ }^{63}$ The manuscript is preserved at the Imperial Museum in Petropolis, Brazil. It was partially transcribed and published on the internet by the Museum of Astronomy and Related Sciences, Rio de Janeiro. See Anonymous, "Aiapana," in A Química e o Dicionário Anônimo de Botânica (Rio de Janeiro: Museu de Astronomia e Ciências Afins), available at: http://site.mast.br/multimidias/botanica/frontend_html/ artigos/index-id=21.html, accessed September 25, 2020.

${ }^{64}$ Édouard Spach, Histoire Naturelle des Végétaux. Phanérogames (Paris: Librairie Encyclopédique de Roret, 1841), v. 10, 290-91. 
from Spach was justified by the issues of the Eupatorium genus, but it was also the corollary of the ayapana globalization process and the knowledge associated with it. ${ }^{65}$ Sixty years after the event narrated by Ferreira with a picturesque tone, the ayapana was no longer a medicinal resource of indigenous peoples to be incorporated into compendiums about the planet's flora and materia medica. In the mid-nineteenth century, it was already present in the main printed pharmacopeia in France and Brazil, such as that by Nicolas Jean-Baptiste Gaston Guibourt, Henrique Velloso de Oliveira and Nicolau Joaquim Moreira. ${ }^{66}$

We can consider this process as originating from the indigenous culture of the Amazon if we consider the truth of Ferreira's statements and that of Carl Friedrich Philipp von Martius, another physician and naturalist like Sigaud, who was very attentive to ethnobotany. Martius mentioned that he had observed the ayapana in São Paulo, where it was used to heal wounds, ${ }^{67}$ and that the plant was collected at the margins of Negro River. ${ }^{68}$ Would this be the river the ayapana originated from? Would the indigenous peoples living in this basin be the ones who did indeed discover its therapeutic value? These questions may not be answered since the indigenous knowledge was not explicitly documented in the sources.

Christopher Parsons analyses this appropriation process and subsequent elision of the local knowledge very well. The author states that the experience of the contact with the local population allowed several colonial agents to learn about the fauna, the flora, and the entire native universe. Although this contact was marked by the "invisibility of the exchanges," it still was a fundamental point in the production of knowledge about the American flora. ${ }^{69}$ For this reason, indigenous history — associated with the history of science—can be useful for analysing the sources previously studied only from the point of view of colonial discourse. More research effort should be put toward highlighting the indigenous agency in several areas of life in the

65 Spach's review, however, went unnoticed by John Gilbert Baker, one of the curators of the Kew Botanical Garden in England, when he wrote, in 1876, the fascicle about the Eupatoriacea family for "Flora Brasiliensis." Baker kept the name created by Vahl. Only in 1970 the Americans Robert Merrill King and Harold Ernest Robinson, in a new revision, stabilized the scientific name of ayapana as Ayapana triplinervis (Vahl) R.M. King \& H. Rob., that is, they recognized Vahl's priority, but kept it in the genus created by Spach. See John Gilbert Baker, "Compositae. II. Eupatoreaceae," in Flora Brasiliensis, ed. Carl Friedrich Philipp von Martius and August Wilhelm Eichler, v. 6, part 2 (München: Frid. Fleischer, 1876), column 306-7; Robert Merrill King and Harold Ernest Robinson, "Studies in the Eupatorieae (Compositae). XXX. The genus Ayapana," Phytologia 20, no. 3 (1970): 210-12.

${ }^{66}$ Nicolas Jean-Baptiste Gaston Guibourt, Histoire Naturelle des Drogues Simples (Paris: J.-B. Baillière, 1850), Tome Troisième, 59-60; Henrique Velloso de Oliveira, Systema de Materia Medica Vegetal (Rio de Janeiro: Eduardo \& Henrique Laemmert, 1854), 101, 228; Nicolau Joaquim Moreira, Diccionario de Plantas Medicinaes Brasileiras (Rio de Janeiro: Typographia do Correio Mercantil, 1862), 18, 68, 142.

67 Johann Baptist von Spix and Carl Friedrich Philipp von Martius, Reise in Brasilien, First Part (München: M. Lindauer, 1823), 279.

${ }^{68}$ Baker, "Compositae. II. Eupatoreaceae," column 307.

${ }^{69}$ Parsons, "Plants and Peoples." 
Amazon valley, including local participation in the production and circulation of scientific knowledge.

\section{The invisible agents of science: the place of indigenous peoples in the history of scientific knowledge}

Ayapana's history is just an example of what can be found in the sources from the eighteenth and nineteenth centuries, where there is abundant information about the role played by indigenous peoples in building the Amazon natural world inventory. There are other cases that still demand the attention of historians, and they can be observed in sources such as the correspondence between the governors of Grão-Pará and the Portuguese Court, which is rich in information about the colonial society, and also the work by António Ladislau Monteiro Baena, with encyclopaedic pretensions and based on extensive documentation. In a letter addressed to his brother written in 1799, for instance, governor Francisco de Souza Coutinho attributed to the Karajá people the "discovery" of a tree, "whose bark, wood and leaves prepared in different ways" helped patients stricken by dropsy. ${ }^{70}$ In turn, Baena mentioned the visit of "two leaders" of the Munduruku people to Belém in 1804, with the purpose of meeting the new governor of Grão-Pará, D. Marcos de Noronha e Brito, earl of Arcos. The governor ordered that a hut be built next to his palace to lodge both leaders and regularly invited them at his table. Aware of the Portuguese interest in the region's natural resources, the Munduruku chiefs gifted the new governor with a plant. According to Baena, "to these Mondrucús [Munduruku] we owe the knowledge about the Ararani tree; whose leaves reduced to ashes works as an antidropsy medicine." ${ }^{11}$

Thus, it is possible to find in the sources, even the most known ones, a regular flow of knowledge and specimens between indigenous peoples and the colonial society. We may follow these specimens and knowledge in letters, memories, travel journals, custom tables, lists of plants and animals, maps, and many other documents of different formats and in which the indigenous protagonism is explicit or can be found between the lines. Their role is clear in the inventory of fauna and flora, exploration of natural resources, development of processing, packaging and transport technologies, codification, and dissemination of useful knowledge to the colonial enterprise. Investigating these practices is essential for analysing the institutionalization process of natural sciences, since they allow the visualization of sociotechnical networks that comprise

\footnotetext{
${ }^{70}$ Francisco de Souza Coutinho to Rodrigo de Souza Coutinho, Pará, 19 April 1799, Correspondência dos Governadores do Grão-Pará com a Corte, Codex 99, v. 20: 147-48, ANRJ.

${ }^{71}$ António Ladislau Monteiro Baena, Compêndio das Eras da Província do Pará (Belém: UFPA, 1969), 260; Baena, Ensaio corográfico, 38, 72.
} 
the illustrated elite, usually of Portuguese origin, and the local population, in a complex appropriation process and cultural miscegenation.

However, that flow of knowledge and specimens was not unidirectional. On the one hand, if most of the knowledge associated with Amazonian plant species clearly comes from indigenous peoples, on the other hand, these peoples also absorbed and adjusted to the knowledge associated with exotic species, as we saw in the case of indigo. The indigo species, exploited in Portuguese America, were most probably native to the continent, as reported by Alexandre Rodrigues Ferreira. According to him, indigo was a "trivial" plant in Tocantins River, where it was known as "wild indigo," growing even in uncultivated soil. This was the plant the region owners used, who "bought the indigo they needed in the same way we buy it in Portugal, where it is not native." 72 However, the entire dye production system adopted by the Amerindians came from Europeans colonial experiences in the East and, later, in the Antilles. According to Prakash Kumar, this system can be seen as transnational, since it was similar in the different places it was implemented until the end of the eighteenth century, with small local variations. ${ }^{73}$

Recent studies have shown that the Portuguese experience in the East was essential for organizing the exploration of some Amazonian species with uncertain use by the indigenous peoples in the seventeenth century. This is the case of the cravo-da-terra (Dicypellium caryophyllaceum [Mart.] Nees). According to Rafael Chambouleyron, the colonial enterprise built around that plant, which was the most relevant after cocoa until the mid-eighteenth century, had as reference not the possible indigenous uses of the species but the exploration and trade carried out by Europeans of an Asian species, which was considered similar to that of the Amazon, the clove coming from India (Syzygium aromaticum [L.] Merr. \& L.M. Perry). In this case, the indigenous peoples were involved in clove collecting and processing because of the knowledge they had of the geographic distribution of the trees. They certainly learned from the Portuguese the industrial processes for preparing the product, as well as their use in medicine and Asian and European cooking. ${ }^{74}$

The investigations related to the indigenous place in the history of scientific knowledge must be expanded, by seeking out new sources and examining the already known ones in the search for practices that show the capability of these peoples in coding, spreading, and adapting knowledge in different contexts. We believe that new research that advance in the visibility

\footnotetext{
${ }^{72}$ Ferreira, "Estado presente," 5.

${ }^{73}$ Prakash Kumar, "Planters and Naturalists: Transnational Knowledge on Colonial Indigo Plantations in South Asia," Modern Asian Studies 48 (2014): 720-53. For a broader study on circulation of knowledge between Asia and Europe, in both directions, see Kapil Raj, "Surgeons, Fakirs, Merchants, and Craftsmen: Making L'Empereur's Jardin in Early Modern South Asia," in Relocating Modern Science: Circulation and the Construction of Knowledge in South Asia and Europe, 1650-1900, ed. Kapil Raj, 2759 (London: Palgrave Macmillan, 2007).

${ }^{74}$ Chambouleyron, "Cacao, Bark-Clove and Agriculture.”
} 
and understanding of agricultural and extractive, medicinal and pharmaceutical, food and industrial practices that were developed throughout the seventeenth, eighteenth and nineteenth centuries is essential to reframe the Amazonian indigenous peoples in the history of sciences, particularly neotropical botany and agronomy. According to Neil Safier, practices of this nature can be observed by means of specimens and objects put into circulation by indigenous peoples, as long as the historian has some sensitivity toward non-normative epistemologies and is able to offset the ethnocentric bias present in the sources:

ethnographic data drawn from necessarily biased sources needs to be supplemented by other strategies, including following itineraries across linguistic and imperial boundaries, borrowing from conceptual categories in other disciplines, and looking for ways that "prehistorical" categories can inform historical development in the past and in the present. What is required are modes of inquiry that highlight particular local contexts in a system of exchanges that was perpetually in motion. A grand, linear narrative seems harder to maintain when our own scholarly itineraries through these knowledge networks reveal connections that were not immediately apparent to those whose worlds we later imagine and reconstruct. ${ }^{75}$

In addition to the relation between local contexts and broader exchange systems, which was mentioned by Safier and presupposes more complex scales and analysis methods, it is also possible to give visibility to indigenous knowledge in long-term colonial processes. Recent research has shown that, even in a hostile environment of continuous expropriation and enslavement, indigenous peoples were able to reinvent their own agricultural practices, by adjusting to the new rurality imposed by the colonial society in the seventeenth and eighteenth centuries. In many locations in Maranhão and Grão-Pará, the peoples who were moved to missionary settlements adjusted their old practices to this new space, and turned into emancipated farmers, who were integrated to the new land distribution and food production system. A similar phenomenon took place in the case of the sesmarias (land concession) given by the Portuguese Crown, a colonial instrument that was perceived by different peoples as land access strategy and opportunity for ensuring survival. According to Rafael Chambouleyron and colleagues:

In this new social and economic situation, the "colonial Amerindians," in addition to manual workers, became the intermediaries between the Portuguese and several populations of indigenous ethnocultural matrix that permeated the colonial order with unforeseen dynamics. ... We can state that the Amerindians also became the colonial Amazon landscape builders, not just because they intervened in and changed the environment, but also because their work for space transformation by agricultural activities was noticed and acknowledged—although in fragmentsby the Portuguese themselves. Hence the roças, taperas, currais or sitios [farmsteads, taperas, corrals or farms] described in the documentation. Thus, in addition

75 Neil Safier, "Global Knowledge on the Move: Itineraries, Amerindian Narratives, and Deep Histories of Science," Isis 101, no. 1 (2010): 133-45, on 145. 
to workers and slaves, border guardians, pilots, oarsmen, troop allies, enemies in wars, runaways, the colonial Amerindians were also ploughmen-as their ancestors had been over time. ${ }^{76}$

We can add that the construction of the colonial Amazon landscape was a long-term process that was not just linked to rurality produced from the intersection between indigenous agricultural practices and colonial instruments, particularly that of territory access and control, but also to the circulation of plants and all the knowledge and technology required for that. By highlighting the different examples of the indigenous protagonism in exploring plant species and retrieving the different international circuits that played a part in the globalization of the ayapana, our intention with this article is to emphasize the dependence of the colonial enterprise on knowledge intrinsic to indigenous peoples. We also shed light on the process of appropriating that knowledge and how it was requalified by the translation from other epistemological systems and integrated into broader, international networks, while eliding the origin and authors of that knowledge from the narratives. Accordingly, we hope to have contributed to a better understanding of the process of transmission, translation and appropriation of knowledge related to the Amazonian natural world, a process that materialized in the continuous, two-way flow of specimens and information between indigenous peoples and colonial society.

\section{Acknowledgements}

The authors thank Dr. Márcio Meira (Goeldi Museum) for recommending some sources for this research and generously reading the paper. Any mistake that may occur is our own responsibility. The paper was translated by Tessa Bueno and revised by Bruna Reis and the journal editorial staff.

\section{Competing interests}

The authors have declared that no competing interests exist.

${ }^{76}$ Rafael Chambouleyron, Karl Arenz and Vanice Siqueira de Melo, "Ruralidades indígenas na Amazônia
colonial," Boletim do Museu Paraense Emílio Goeldi. Ciências Humanas 15 (2020): e20190027, on 16-7. 